\title{
CHARACTERISATION OF COAT COLOUR IN THE SLOVENIAN POSAVJE HORSE
}

\author{
Gertrud Grilz-Seger ${ }^{1 *}$, Matjaž Mesarič2* ${ }^{2 *}$ Gottfried Brem¹, Marko Cotman³ \\ *the authors equally contributed to this work \\ ${ }^{1}$ Institute of Animal Breeding and Genetics, University of Veterinary Sciences Vienna, Veterinärplatz 1, A-1210 Vienna, Austria, ${ }^{2}$ Clinic for \\ Reproduction and Large Animals, University of Ljubljana, Veterinary Faculty, Cestav Mestni log 47, Institute for Preclinical Sciences, University \\ of Ljubljana, Veterinary Faculty, Gerbičeva 60, 1000 Ljubljana, Slovenia \\ *Corresponding author, E-mail: gertrud.grilz@vetmeduni.ac.at
}

\begin{abstract}
Different approaches and classification systems have been established to describe equine coat colour, which varies between breeds and countries. In the present study, we first characterised the coat colour variability in the Slovenian Posavje Horse applying colour spectrophotometry following the CIE L*a*b system. As derived from the classification system of Sponenberg (light bay, bay, mahogany bay, brown and seal brown), the phenotype categories could be confirmed by spectrophotometric data. Furthermore, $L^{*} a^{*} b$ values revealed comparable high phenotypic variability of bay coat colour in the Posavje breed, and the darker shades of bay coat colour were associated with the ASIP and MC1Rgenotype combination A/a E/E. CIE L*a*b colour spectrophotometry represents an effective tool to characterise and quantify coat colour in horses, especially in chestnut horses, for which the underlying genetic background of coat colour variation remains unknown.
\end{abstract}

Key words: Posavje Horse; MC1R; ASIP; coat colour; spectrophotometry; CIE L*a*b

\section{Introduction}

Breeding for coat colour has been a part of horse breeding throughout history and represented a central objective since prehistoric times (1-4). Due to the high economic, aesthetic, and health impacts, coat colour has been in the focus of genetic research in recent decades. The genetic background of the base coat colours bay, black and chestnut, predominantly occurring in Posavje Horses has been determined. Marklund et al. (5) identified a missense mutation in the gene melanocyte-stimulating hormone receptor

Received:23 April 2020

Accepted for publication:23 December 2020
$(M C 1 R)$, responsible for chestnut coat colour. Rieder et al. (6) detected an 11-bp deletion in exon 2 of the ASIP (Agouti signalling protein) gene, resulting in black coat colour. Nevertheless, the background of the bright variety of shades within bay and chestnut is not fully resolved. In addition to studying environmental effects influencing colour shades $(7,8)$, researchers have investigated genotype interactions of $A S I P$ and $\operatorname{MC} 1 R(6,9,10)$; in these publications, the genotype combination $A / a E / E$ was associated with darker shades of bay.

In the studies of Rieder et al. (6) and Sakamoto et al. (10), the classification of the different coat colour shades was derived by visual inspection, whereas Druml et al. (9) used a colour-spectrophotometer to define exact coat colour groups. 
For the quantification of coat colour, the use of a spectrophotometer and the standardised $L^{*} a^{*} b^{*}$ colour system as defined by the Commission Internationale de l'Eclairage (CIE), has proven to be helpful in a series of studies. For example, this procedure was applied to investigate the greying process in Lipizzan (11) and Kladrub horses (7). It was further utilised for the estimation of additive genetic effects of coat colour in Noriker horses (12), Lipizzan, Nonius, Arabian Purebred, Shagya Arabian, Gidran (13), and Black Kladrub horses (7) and for quantifying genotype interactions in Noriker and Shagya Arabian horses (9).

This study aimed to characterise base coat colour variation in the Slovenian Posavje Horse with particular focus on bay coat colour, using spectrophotometric measurements. In the Posavje Horse, a small autochthonous draught horse breed, a wide spectrum of base colour shades exists. We quantified and validated the classification categories derived by visual inspection, and compared the measurements with those of Noriker horses and Shagya Arabians, two horse breeds for which darker phenotypes are preferred by the breeders. Furthermore, we investigated the association between genotype combinations of ASIP and MC1R and coat colour variation.

\section{Materials and methods}

The Posavje Horses included in this study were selected to represent the whole spectrum of coat colour variability in this breed. We measured 70 adult Posavje Horses ( $<3$ years of age) during the summer months of 2018 using a Chroma Meter CL-100 (Konica Minolta, Japan). From these 70 horses, 55 were bay, ten were chestnut, and five were black. All animals were phenotyped by visual inspection according to the system of Sponenberg (14).

Measurements were taken from five different body areas, including the neck, shoulder, axillary area, belly, and croup (Figure 1). Colour, as defined by the CIE L*a*b* colour space, consists of three axes defining variation from black to white $\left(\mathrm{L}^{*}\right)$ at a scale from 0 to +100 , blue to yellow $\left(b^{*}\right)$ at a scale from -100 to +150 , and green to red $\left(\mathrm{a}^{*}\right)$ at a scale from -170 to +100 . Additionally, we used published data (3) from 24 Noriker (12 bay, 12 black) and 32 Shagya Arabians (30 bay and two black), which were measured using the same Chroma Meter CL-100 (Konica Minolta, Japan) and methodology previously described. In total, data of 126 horses were used for this study.

To determine the ASIP and MC1R genotypes, genomic DNA was isolated from $300 \mu$ whole blood with a Wizard Genomic DNA Purification Kit (www.promega.com) according to manufacturer's instructions. The coat colour gene loci were genotyped using restriction fragment length polymorphism (RFLP) methods for $M C 1 R$ (15) and polymerase chain reaction (PCR) techniques for ASIP (6).

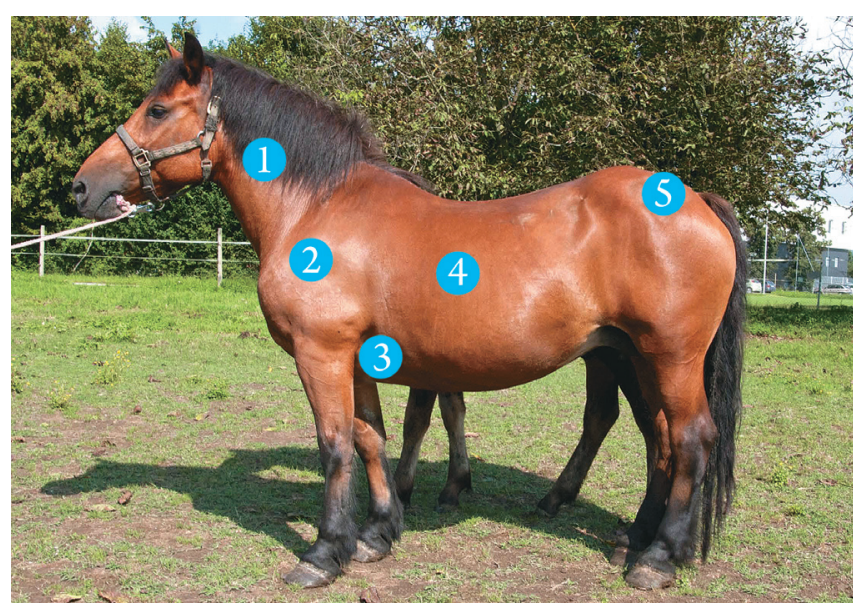

Figure 1: Coat colour was measured at five different body areas: 1 =neck, $2=$ shoulder, $3=$ axillary area, $4=$ belly, and $5=$ croup (Foto: Matjaž Mesarič)

We applied MANOVAand canonical discriminant analysis in order to analyse differences in colour measurements between a) classification categories of bay coat colour and $b$ ) genotype combinations of ASIP and MC1R comprising horses of all base colours. For the MANOVA, we applied two generalised linear models, which included a) coat colour classification categories as a fixed effect $\left(\mathrm{y}_{\mathrm{ik}}\right.$ $=$ classification $_{\mathrm{i}}+\mathrm{e}_{\mathrm{k}}$ ) and $\left.\mathrm{b}\right) A S I P / M C 1 R$ genotype as a fixed effect $\left(\mathrm{y}_{\mathrm{ik}}=\right.$ genotype $\left._{\mathrm{i}}+\mathrm{e}_{\mathrm{k}}\right)$. In order to test the differences of $\mathrm{L}^{*} \mathrm{a} * \mathrm{~b}$ measurements between the four genotype combinations in bay horses, we performed a comparison of LSMeans correcting for multiple level using the Tukey-Kramer test.

Canonical discriminant analysis is a multivariate technique that can be used to determine relationships among categorical variables and groups of independent variables.

The canonical discriminant function searches for linear combinations of independent variables in a data set to achieve maximum separation of classes (populations), in this case, ASIP/MC1R genotypes, in a lower dimensional discriminant 
space. A major task of this method is to test and visualise the discrimination power based upon the canonical variables. The resulting discrimination plots assist in analysing and discussing the underlying data and results derived from other statistical procedures. In this study, we performed a canonical discriminant analysis to determine the colour measurements of all Posavina horses (bay, black, chestnut) according to their ASIP/MC1R genotypes. All statistical analyses and graphical representations were performed using the SAS software package (16).

\section{Results}

Phenotypic classification by visual inspection revealed a high variability in shades of bay and chestnut Posavje Horses. In chestnut horses, both classification categories, chestnut and sorrel (light mane and tail), were present, and phenotypic variability ranged from light sorrel to dark chestnut (Figure 2). Comparable variation was observed in bay horses, for which coat colour categories ranged from light bay up to seal brown. Most of the horses were classified bay (41.8\%), followed by $23.7 \%$ mahogany bay. Dark shades were represented by $16.3 \%$ brown horses, of which $1.8 \%$ were seal brown. Light shades (light bay, red bay) were present in $16.4 \%$ of horses (Figure 3).
Black horses were predominantly summer black.

According to the CIE L*a*b measurements, the mean L-values describing the brightness from white to black, ranged in black horses from 19.9 (belly) to 22.9 (axillary are). The mean a-values, defining the colour axis from green to red, were lowest in the neck area $(a=1.7)$ and highest in the axillary area $(a=3.2)$. Finally, in black horses the mean b-values, characterising the blue to yellow axis, varied between 2.5 (belly) and 4.1 (axillary area) (Tab. 1).

The mean L-values in bay horses ranged from 26.3 (neck) to 37.0 (axillary area), mean a-values varied from 7.4 (neck) to 9.5 (belly) and mean b-values were in between 9.5 (neck) and 17.6 (axillary area) Table 1). Highest individual L-values were measured in the axillary area $(\mathrm{L}=52.9)$, and the darkest points were measured in the neck area $(\mathrm{L}=16.2)$. The darkest bay colour categories (seal brown, brown and dark mahogany bay) exhibited partially comparable measurements on the L-axis in neck and croup area (L from 16.2 to 27.1) as observed in black horses.

In chestnut horses, individual L-values ranged from 26.1 (neck) to 61.2 (axillary area), whereas the means covered the range from 29.3 (neck) to 42.7 (axillary area) and thus overlapped with the measurements of bay horses from medium to light colour categories (bay to light bay).

Table 1: Mean values, standard deviation (SD) for $\mathrm{L}^{*}, \mathrm{a}^{*}, \mathrm{~b}^{*}$ measured at five different body ares for black, bay and chestnut Posavje Horses

\begin{tabular}{|c|c|c|c|c|c|c|c|}
\hline \multirow{2}{*}{$\begin{array}{l}\text { Measuring } \\
\text { point }\end{array}$} & \multirow[t]{2}{*}{ Variable } & \multicolumn{2}{|c|}{ black } & \multicolumn{2}{|c|}{ bay } & \multicolumn{2}{|c|}{ chestnut } \\
\hline & & mean & $\mathrm{SD}$ & mean & $\mathrm{SD}$ & mean & SD \\
\hline Neck & & 20.42 & 2.08 & 26.26 & 3.94 & 29.29 & 3.18 \\
\hline Shoulder & & 22.30 & 1.48 & 30.29 & 4.00 & 33.20 & 2.15 \\
\hline Axillary area & $L^{*}$ & 22.92 & 1.95 & 37.01 & 6.13 & 42.72 & 8.41 \\
\hline Belly & & 19.92 & 4.12 & 32.25 & 4.30 & 34.63 & 3.97 \\
\hline Croup & & 22.24 & 1.23 & 27.86 & 4.17 & 30.55 & 2.82 \\
\hline Neck & & 1.70 & 1.05 & 7.42 & 2.75 & 9.37 & 1.57 \\
\hline Shoulder & & 2.46 & 1.50 & 8.55 & 2.12 & 8.84 & 1.13 \\
\hline Axillary area & $a^{*}$ & 3.16 & 1.26 & 9.03 & 1.98 & 8.03 & 2.20 \\
\hline Belly & & 2.26 & 0.96 & 9.51 & 2.27 & 9.06 & 1.23 \\
\hline Croup & & 2.48 & 1.57 & 7.69 & 2.51 & 8.89 & 1.42 \\
\hline Neck & & 2.74 & 2.57 & 9.47 & 4.41 & 12.49 & 2.95 \\
\hline Shoulder & & 2.54 & 1.84 & 12.58 & 4.13 & 14.94 & 2.56 \\
\hline Axillary area & $b^{*}$ & 4.12 & 1.78 & 17.61 & 4.00 & 18.11 & 1.40 \\
\hline Belly & & 2.46 & 1.86 & 14.68 & 3.80 & 15.57 & 3.05 \\
\hline Croup & & 3.04 & 2.61 & 10.60 & 4.04 & 13.28 & 2.68 \\
\hline
\end{tabular}


Measurements of a-values (red-green axis) generally overlapped with those of bay horses $(a=8.0$ (axillary area) to $a=9.4$ (neck)), whereas the colour variation in the direction of yellow was more pronounced with mean $b$-values ranging from 12.5 (neck) to 18.1 (axillary area). On an individual level, the b-values were between 9.0 (neck) and 19.2 (axillary aera).

Multiple comparisons of means adjusted according to the method of Tukey and Kramer revealed that the $L^{*} a^{*}$ and $b^{*}$ measurements resulted in significant differences between the colour classification categories of bay coat colour. Accordingly, light bay differed from mahogany bay and brown $(\mathrm{p}<0.05)$. In the axillary area area, light bay, seal brown, and mahogany bay could not be distinguished, only brown horses were more darkly pigmented in this area. Light bay horses exhibited the most similarity to chestnut horses expressed in L- and b-values measured at neck, belly, and croup. Slight deviations were identified in the a-values of the measuring areas of the shoulder and axillary.
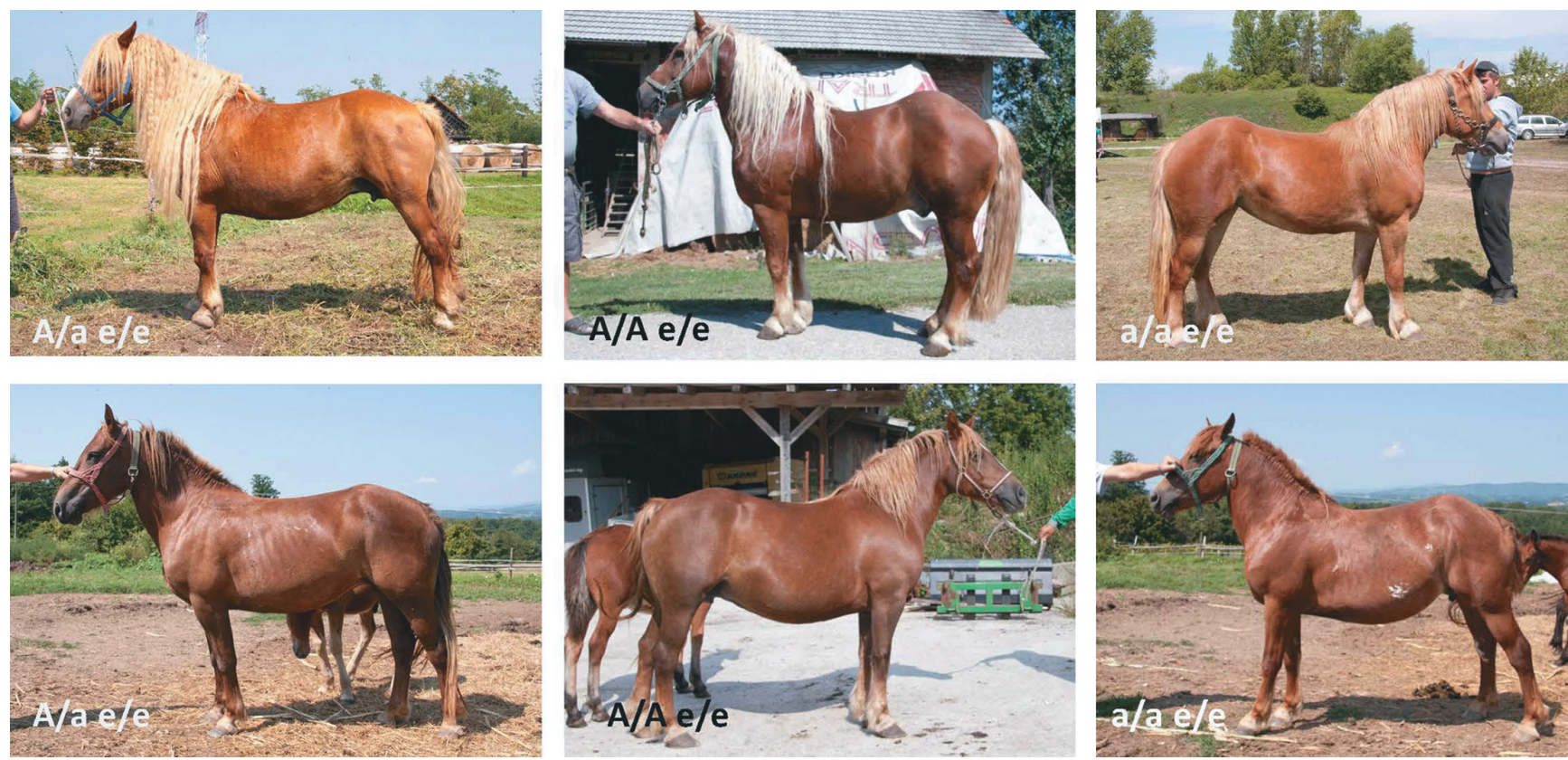

Figure 2: Chestnut/sorrel phenotypes and MC1R/ASIP genotypes (Fotos Matjaž Mesarič)
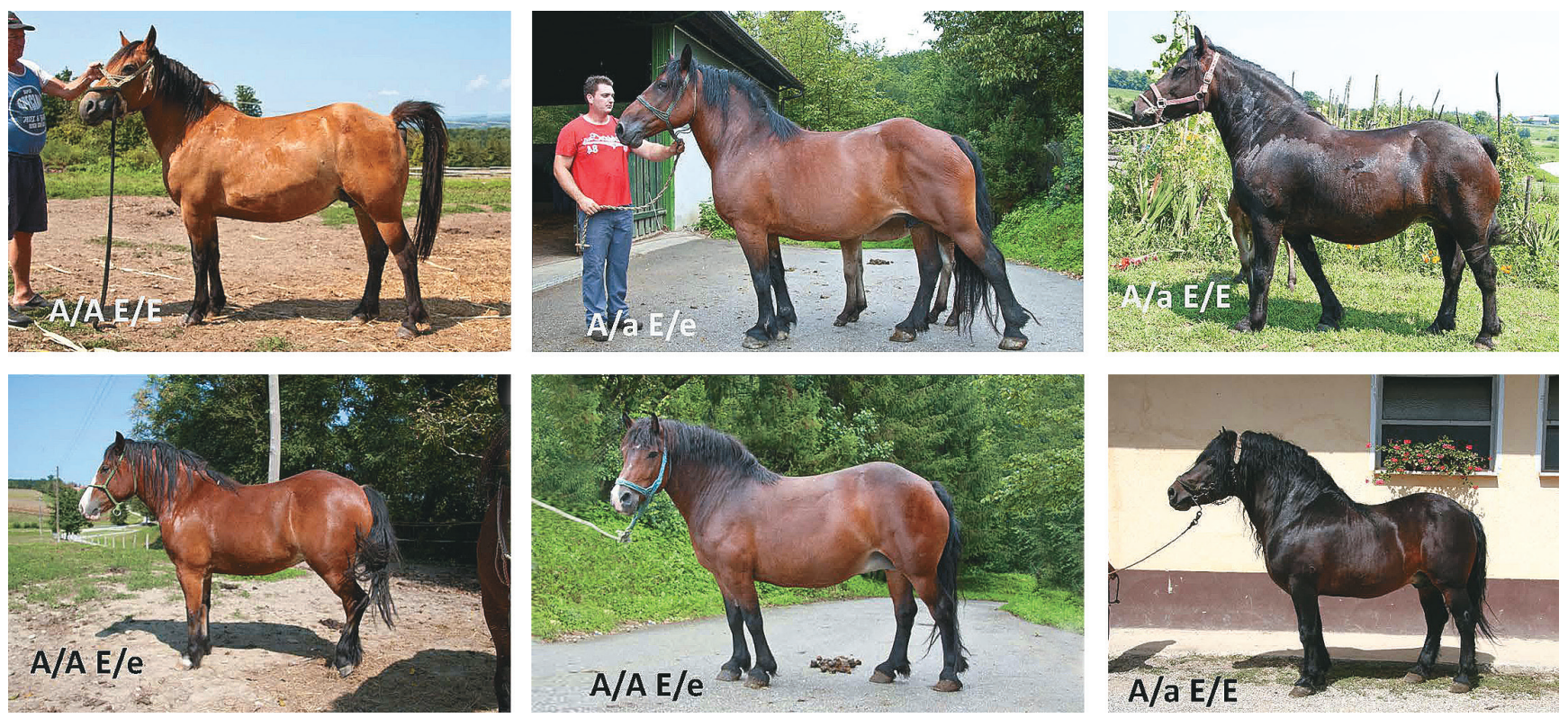

Figure 3: Bay phenotype classification categories (first line: light bay, bay, brown; second line: red bay, mahogany bay, dark mahogany bay) and genotypes of $M C 1 R$ and ASIP (Fotos Matjaž Mesarič) 
From 70 genotyped horses, five were black (3a/a E/E, $2 a / a E / e$ ), and within the 55 bay Posavje Horses the genotype combination $A / a$ $E / E$ was most frequent $(52,7 \%)$. The genotypes $A / A E / E$ and $A / a E / e$ were present with $20 \%$ each, and $7.3 \%$ of the horses had the genotype $A / A$ e/E (Figure 3). Within the ten chestnut/ sorrel Posavje Horses, all genotype combinations (3 A/A e/e, $5 \mathrm{~A} / \mathrm{a}$ e/e, 2 a/a e/e) were observed (Figure 2).

Pooling all base-coloured Posavje Horses to- gether, canonical discriminant analysis, which differentiated the spectrophotometric data $\left(L^{*} a^{*} b\right)$ according to the ASIP and $M C 1 R$ genotype combinations $(a / a$ e/e, $a / a E / E, a / a E / e, A / A E / E, A / a$ $E / E, A / a E / e)$, resulted in three main clusters: one cluster containing all black horses $(3 a / a$ $E / E, 2 a / a E / e)$, a second wider spread cluster containing mostly darker shaded bay horses $(A / a$ $E / E)$, and a third heterogeneous cluster containing lighter shaded horses of all bay genotype combinations and the ten chestnut horses (Figure 4.).

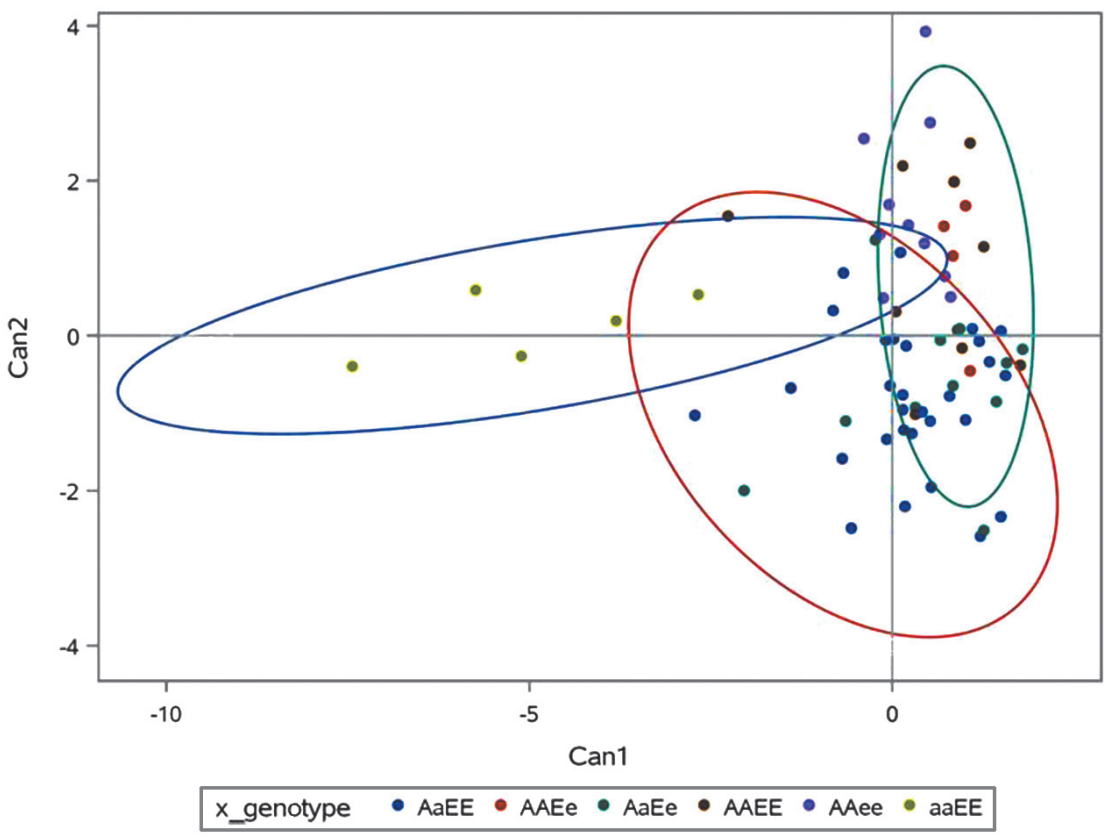

Figure 4: Plot of the first two canonical variables (Can1 and Can2) derived from canonical discriminant analysis discriminating individual colour phenotype information $\left(\mathrm{L}^{*} \mathrm{a} * \mathrm{~b}\right)$ according to genotype information of $M C 1 R$ and $A S I P$. Can 1 explained $55.3 \%$ of the between group variation and Can 2 accounted for $27.2 \%$ of the between group variation

\section{Breed Comparison}

In comparison to the Noriker horse and the Shagya Arabian, Posavje Horses exhibited the highest variability in $L^{*}$ measurements and had a higher proportion of lighter shades of bay. However, Posavje Horses and Shagya Arabians were characterised by higher $L^{*} a * b$ values than those of the Noriker horses (Figure 5).

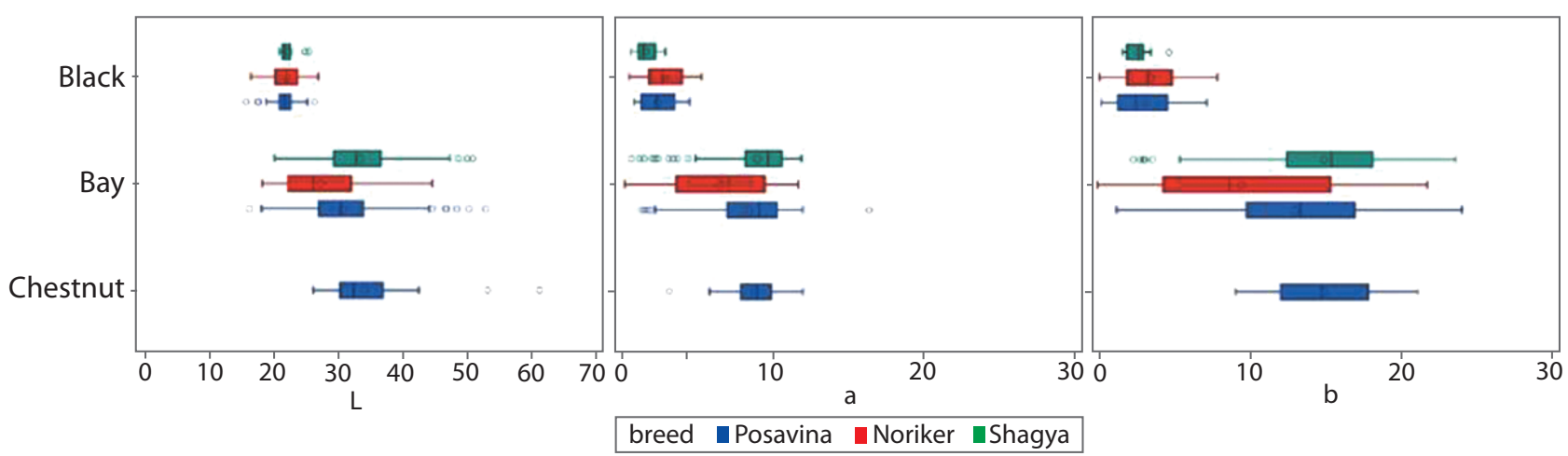

Figure 5: Box plots for $L^{*} a * b$ measurements of all body areas in bay, black, and chestnut Posavje Horses, bay and black Noriker and Shagya Arabian horses 
Following a MANOVA in order to test the differences of $L^{*} a^{*} b$ measurements between the four genotype combinations in bay horses from the breeds Posavje, Noriker and Shagya Arabian, the generalised model and the Tukey-Kramer test revealed significant differences in all measuring spots between the dark shade associated $A / a$ $E / E$ genotype and most of the other genotype combinations $(A / A E / E, A / a E / e, A / A E / e)$, except at the axillary area, where the a-value did not differ significantly between the genotype combinations (see Tab. 2.).

Table 2: LSmean values for the four genotype groups of $A S I P$ and $M C 1 R$ for all five measuring points in 97 bay Noriker, Posavina and Shagya Arabian horses. Superscripts in small letters indicate significant differences between LSmeans at a p-value $<0.05$

\begin{tabular}{|c|c|c|c|c|c|c|}
\hline & & Rsq & $A / A E / E$ & $A / A E / e$ & $A / a E / E$ & $A / a E / e$ \\
\hline \multirow[t]{3}{*}{ Neck } & $\mathrm{L}^{*}$ & 0.23 & $27.63^{b}$ & $30.99^{b}$ & $25.00^{a}$ & $27.95^{b}$ \\
\hline & $a^{*}$ & 0.26 & $8.09^{b}$ & $9.63^{\mathrm{b}}$ & $5.88^{\mathrm{a}}$ & $8.88^{\mathrm{b}}$ \\
\hline & $b^{*}$ & 0.24 & $11.03^{\mathrm{b}}$ & $14.06^{\mathrm{b}}$ & $7.73^{\mathrm{a}}$ & $11.57^{\mathrm{b}}$ \\
\hline \multirow[t]{3}{*}{ Shoulder $^{1}$} & $\mathrm{~L}^{*}$ & 0.16 & 31.01 & $33.18^{b}$ & $28.45^{\mathrm{a}}$ & 30.90 \\
\hline & $a^{*}$ & 0.22 & $8.99^{b}$ & $9.73^{\mathrm{b}}$ & $7.11^{\mathrm{a}}$ & $9.42^{\mathrm{b}}$ \\
\hline & $\mathrm{b}^{*}$ & 0.18 & $13.22^{\mathrm{b}}$ & $15.25^{b}$ & $10.46^{\mathrm{a}}$ & $13.52^{\mathrm{b}}$ \\
\hline \multirow[t]{3}{*}{ Axillary area } & $\mathrm{L}^{*}$ & 0.10 & 39.35 & $42.87^{b}$ & $36.17^{\mathrm{a}}$ & 38.02 \\
\hline & $a^{*}$ & 0.10 & 9.68 & 9.65 & 8.39 & 9.60 \\
\hline & $b^{*}$ & 0.13 & $19.26^{b}$ & $19.89^{b}$ & $16.37^{\mathrm{a}}$ & 18.57 \\
\hline \multirow[t]{3}{*}{ Belly } & $\mathrm{L}^{*}$ & 0.15 & $33.53^{b}$ & $35.09^{b}$ & $30.02^{a}$ & 33.49 \\
\hline & $a^{*}$ & 0.14 & $10.09^{b}$ & $10.53^{b}$ & $8.27^{\mathrm{a}}$ & $10.14^{b}$ \\
\hline & $b^{*}$ & 0.14 & $15.74^{\mathrm{b}}$ & $17.06^{\mathrm{b}}$ & $12.64^{\mathrm{a}}$ & 15.88 \\
\hline \multirow[t]{3}{*}{ Croup } & $\mathrm{L}^{*}$ & 0.09 & 27.52 & $29.18^{b}$ & $25.71^{a}$ & 28.27 \\
\hline & $a^{*}$ & 0.16 & $7.85^{\mathrm{b}}$ & $8.57^{\mathrm{b}}$ & $5.71^{\mathrm{a}}$ & $9.10^{\mathrm{a}}$ \\
\hline & $b^{*}$ & 0.13 & 10.76 & $12.09^{b}$ & $7.88^{\mathrm{a}}$ & 10.88 \\
\hline
\end{tabular}

${ }^{1} 92$ animals (5 were missing shoulder measurements)

\section{Discussion}

The three base colours represent the typical coat colour spectrum of the Posavje Horse; the bay coat occurs predominantly and is favoured by the breeders (17). Within the breeding objectives, there is no preference for special shades. As a result, no selection towards distinct chestnut or bay coat colour shades exists. Therefore, in the Posavje breed, a high variation in bay and chestnut is present, whereas in Noriker horses, mahogany bay and brown are preferred, and lighter variants are rare (9). The results of the study showed that the classification categories of Sponenberg (14) can be verified with colour spectrophotometric data. Light bay is characterised by the highest L-values, which are similar across all measuring points, whereas brown is defined by lower and equally dispersed $L^{*} a * b$ values. In mahogany bay, which ranges in the $L^{*} a * b$ spectra between light bay and brown, differences between measuring points occurred. The darkest areas were observed at the neck and croup measuring points, whereas the shoulder and belly were lighter. Lower values of $\mathrm{L}^{*} \mathrm{a} * \mathrm{~b}$ in measuring points of the dorsal body area were also observed by Hofmanova et al. (7). In seal brown, which represents the darkest bay category, the typical characteristic is represented by lighter (L-value) and yellowish (b-value) colour measures around the axillary area. Chestnut horses (although the number of animals included in this study were too low for more detailed analysis) could not be differentiated from bay or light bay horses by spectrophotometric data (long hair was not measured).

Breed-specific differences in $\mathrm{L}^{*} \mathrm{a}^{*} \mathrm{~b}$ measurements could be shown for Posavje, Noriker and Shagya Arabian horses, whereas in the Noriker sample the darkest phenotypes in the bay and black horses were observed and bay Shagya Arabians exhibited the lightest colour measurements. Toth et al. (13) observed lower $L^{*} a^{*} b$ within the Hungarian Nonius breed, for which the selection allows only dark shades of bay and black. The values 
for Nonius ( $L=24.0 ; a=4.5 ; b=4.8$ ) were even lower than in the in Noriker sample.

The phenotypic differences between chestnut and sorrel horses were investigated by Reissmann et al. (18), who were not able to prove a direct relation between genotype and the colour differences of long hair (tail, mane) and body hair. Furthermore, no association between chestnut colour shades and the second identified mutation $\mathrm{e}^{\mathrm{a}}$ in $M C 1 R$ (19) was observed. The presence of this mutation was documented in Black Forest Horse, Hungarian Coldblood (20) and in Haflinger breeds (21). Rieder et al. (6) concluded from a small sample of chestnut horses that no association of chestnut coat colour variation with allele status on the ASIP locus, whereas Grilz-Seger et al. (22, 23) postulated that the gene OCA2 may be involved in chestnut coat colour variation and in the mealy (pangare) phenotype. Rieder et al. (6), who analysed associations of MC1R and ASIP allele status with colour variation in bay horses, concluded an association of $E / E M C 1 R$ genotype with darker shades of bay. In a recent association study, Corbin et al. (24) confirmed the results of Rieder et al. (6). Sakamoto et al. (10), who conducted a pedigree analysis and tested offspring ratios, also observed an association between $A$ / $a$ genotype at the Agouti locus and $E / E$ genotype at the Extension locus with dark shades of bay. In our study, we were able to confirm these findings and could show that dark shades of bay were associated with the genotype combination $A / a E / E$ in bay Posavje Horses, Noriker, and Shagya-Arabians. Interestingly, a comparable gene interaction of $A S I P$ and $M C 1 R$ was reported in the red fox (Vulpes Vulpes) by Vage et al. (25). Genotype combination $A / A E / E$ resulted in the common phenotype of red foxes, whereas the genotype $A / a E / E$ is characterised by dark colour shades in foxes (25).

Conclusions. CIE $\mathrm{L}^{*} \mathrm{a} * \mathrm{~b}$ colour spectrophotometry represents an effective tool to characterise and quantify coat colour in horses, which could be used for further analysis of chestnut coat colour, for which the genetic background of coat colour variation remains unknown.

\section{Acknowledgements}

This work was financially supported by the Slovenian Research Agency program P4-0053 to M. Cotman.
Hair samples for Posavje Horses were collected in the context of routine procedures during the studbook registration of horses by the Institute for Breeding and Health Care of Horses of the Veterinary Faculty, Ljubljana.

Author's contribution: Grilz-Seger, Gertrud: conceptualisation, data analysis, writing - original draft, Mesaric, Matjaz: sampling, data collection; Cotman, Marko: DNA extraction and genotyping, funding acquisition; Brem, Gottfried: funding acquisition; all authors: reading, commenting and reviewing of the final manuscript draft. None of the authors has conflicts of interest.

\section{References}

1. Wutke S, Benecke N, Sandoval-Castellanos $\mathrm{E}$, et al. Spotted phenotypes in horses lost attractiveness in the Middle ages. Sci Rep 2016; 6: e38548. doi: 10.1038/srep38548

2. Pruvost M, Bellone R, Benecke N, et al. Genotypes of predomestic horses match phenotypes painted in Paleolithic works of cave art. Proc Natl Acad Sci U S A 2011; 108: 18626-30.

3. Librado P, Gamba C, Gaunitz C, et al. Ancient genomic changes associated with domestication of the horse. Science 2017; 356: 442-5.

4. Ludwig A, Pruvost M, Reissmann M, et al. Coat colour variation at the beginning of horse domestication. Science 2009; 324(5296): e485. doi: 10.1126/science. 1172750 .

5. Marklund L, Moller MJ, Sandberg K, Andersson L. A missense mutation in the gene for melanocyte-stimulating hormone receptor (MC1R) is associated with the chestnut coat colour in horses. Mamm Genome 1996; 7: 895-9.

6. Rieder S, Taourit S, Mariat D, Langlois B, Guérin G. Mutations in the agouti (ASIP), the extension (MC1R), and the brown (TYRP1) loci and their association to coat colour phenotypes in horses (Equus caballus). Mamm Genome 2001; 12: 450-5.

7. Hofmanová B, Kohoutová P, Vostrý L, Vostrá Vydrová H, Majzlik I. Quantitative aspects of coat colour in old Kladruber Black Horses. Poljoprivreda 2015; 21(Suppl.): 224-7.

8. Stachurska A, Pięta M, Jaworski Z, Ussing AP, Bruśniak A, Florek M. Colour variation in blue dun Polish Konik and Biłgoraj horses. Livest Prod Sci 2004; 90(2): 201-9.

9. Druml T, Grilz-Seger G, Horna M, Brem G. Discriminant analysis of colour measurements 
reveals allele dosage effect of ASIP/MC1R in bay horses. Czech J Anim Sci 2018; 63: 347-55.

10. Sakamoto T, Fawcett JA, Innan H. Evaluating the potential roles of the Gray and Extension loci in the coatcoloration of Thoroughbred racing horses. J Equine Sci 2017; 28: 61-5.

11. Curik I, Druml T, Seltenhammer M, et al. Complex inheritance of melanoma and pigmentation of coat and skin in grey horses. PLoS Genetics 2013; 9: e1003248.

12. Lackner C. Quantitative Ansätze der Farbvererbung beim Noriker-Pferd: Dipl. Arbeit. Wien : Universität für Bodenkultur, 2006.

13. Toth Z, Kaps M, Sölkner J, Bodo I, Curik I. Quan $\neg$ titative genetic aspects of coat color in horses. J Anim Sci 2006; 84: 2623-8.

14. Sponenberg DP. Equine color genetics. 3rd ed. Hoboken : Wiley-Blackwell, 2009: p. 118.

15. Lauren J, Staiger E, Albright J, Brooks S. The MC1R and ASIP coat colour loci may impact behavior in the horse. J Hered 2016; 107(3): 214 9. doi: 10.1093/jhered/esw007.

16. SAS Institute. Cary : SAS university edition, Cary, USA, 2018.

17. Mesarič M. Die Zucht des Posavina Pferdes in Slowenien. In: Grilz-Seger G, Druml T, ed. Das Posavina Pferd. Graz : Vehling Verlag, 2018.

18. Reissmann M, Brockmann GA. Analyse verschiedener Langhaaraufhellungen beim Pferd. Züchtungskunde 2008; 80: 491-500.
19. Wagner HJ, Reissmann M. New polymorphism detected in the horse MC1R gene. Anim Genet 2000; 31: 289-90.

20. Reissmann M, Wagner M, Gulyaz L, Schuster $\mathrm{S}$. The allele ea - a rare mutation in the MC1R gene in horses (Equus caballus). In: 28th International Conference on Animal Genetics. Göttingen : International Society of Animal Genetics, 2002.

21. Reissmann M, Musa L S, Zakizadeh S, Ludwig A. Distribution of coat-colour-associated alleles in the domestic horse population and Przewalskis horse, J.Appl Genetics 2016; 57: 519-525.

22. Grilz-Seger G, Druml T, Neuditschko M, et al. Changes in breeding objectives of the Haflinger horse breed from a genome-wide perspective. Züchtungskunde 2019; 91: 296-311.

23. Grilz-Seger G, Neuditschko M, Ricard A, et al. Genome-wide homozygosity patterns and evidence for selection in a set of European and Near Eastern horse breeds. Genes 2019; 10(7): e491. doi: $10.3390 /$ genes 10070491

24. Corbin LJ, Pope J, Sanson J, et al. An independent locus upstream of ASIP controls variation in the shade of the Bay Coat colour in horses. Genes 2020; 11(6): 606. doi: 10.3390/genes 11060606.

25. Vage DI, Fuglei E, Snipstad K, Beheim J, Landsem M, Klungland $\mathrm{H}$. Two cysteine substitutions in the MC1R generate the blue variant of the arctic fox (Alopex lagopus) and prevent expression of the white winter coat. Peptides 2005; 26(10): 1814-7.

\title{
KARAKTERIZACIJA BARVE DLAKE PRI POSAVSKEM KONJU
}

\author{
G. Grilz-Seger, M. Mesarič, G. Brem, M. Cotman
}

Izvleček: Za opis barvkonj se uporabljajo različni pristopi in klasifikacijski sistemi, ki se razlikujejo med posameznimi pasmami in državami. V raziskavi smo najprej opredelili različne barve dlake pri posavskem konju z metodo barvne spektrofotometrije po sistemu CIE L*a*b*. Fenotipsko razdelitev barv dlake po Sponenbergu (light bay/svetli rjavec, bay/rjavec, mahogany bay/ kostanjev, brown/temni rjavec and seal brown/črnkast rjavec) smo potrdili s spektrofotometričnimi podatki. Vrednosti L*a*b so pri posavskem konju pokazale primerljivo visoko fenotipsko variabilnost rjave barve, pri tem so bili temnejši odtenki povezani z ASIP in MC1R kombinacijo genotipa A/a E/E. Barvna spektrofotometrija po sistemu CIE L*a*b predstavlja učinkovito orodje za kvalitativno in kvantitativno opredelitev/določanje barv pri konjih, zlasti pri lisjakih, pri katerih še vedno ni znana genska osnova variabilnosti v barvi dlake.

Ključne besede: posavskikonj; MC1R; ASIP; barva dlake; spektrofotometrija; CIE L*a*b 